\title{
Resilience of Farmers at Water Shortage Situations in Minor Irrigation Systems: A Case Study in Kurunegala District, Sri Lanka
}

\author{
W.M.S.M. Wijekoon ${ }^{*}$, E.R.N. Gunawardena ${ }^{1}$, M.M.M. Aheeyar ${ }^{2}$ and W.P.R.P. De Silva $^{1}$
}

\author{
Postgraduate Institute of Agriculture \\ University of Peradeniya \\ Sri Lanka
}

\begin{abstract}
Farmers in Minor Irrigation Systems (MIS) experience many difficulties due to severe seasonal or year-round absolute water scarcity that affects their livelihoods. In order to address this problem, the resilience of the vulnerable communities needs to be enhanced through smart investments and appropriate adaptation strategies. Since there is no well-established method for assessing the resilience of the farmers in MIS, this study was aimed to develop a framework and prospective methodology to assess resilience and factors determining the resilience to shocks and stresses of MIS. A structured questionnaire survey was carried out among 188 households belong to eight farmer organizations under 16 MIS located in three Agrarian Service Divisions in the $I L_{3}$ agro-ecological region in Kurunegala District. The resilience of farming was measured using adaptive capacity or the risk management strategies used at household levels related to farming practices using 20 indicators. Analysis of factors was performed with the principle component method and rotated (from Varimax with Kaiser Normalization technique) factor loadings were extracted to compute resilience index. Using the empirical equation derived from the study, the resilience of MIS was quantitatively determined. The results showed that there is an adequate space to enhance the resilience of farming in MIS by introducing and adapting various risk management strategies. It appears that capacity of the tank, accessibility of services and the trust of farmers both on farmer organizations and the agency officials are some of the key factors which govern the resilience of farming in MIS.
\end{abstract}

Keywords: Livelihood, minor irrigation system, resilience, risk management, water scarcity

\section{INTRODUCTION}

Village tanks, which provide irrigation water to command areas of less than 80 ha are classified as Minor Irrigation Systems (MIS) and have historically been built to fulfill food security needs of successive generations under water shortage conditions mainly in the Dry and Intermediate zones of Sri Lanka (Siriweera, 2002). The role of the irrigation sector has now become more important than ever before, because of the increasing population, high proportion of people living in rural areas and the large numbers of people dependent on agriculture for their livelihoods (IWMI, 2006). About two million farmer families or $65 \%$ of rural households are engaging in irrigated paddy farming as their main occupation (Shantha and Asan, 2014). Paddy, the main irrigated crop, is grown on nearly 730,000 ha of land of

\footnotetext{
1 Department of Agricultural Engineering, Faculty of Agriculture, University of Peradeniya, Sri Lanka

2 International Water Management Institute, Colombo, Sri Lanka

* Corresponding author: shyam.madu@gmail.com
} 
which 170,000 ha is grown under medium and MIS (Shantha and Asan, 2014). Many factors, which include technical, social and economic and governance issues currently challenge sustainability of the MIS (Thilakasiri, 2015; Wijekoon et al., 2016; Kumara et al., 2017).

Sustainability of agriculture is centered on concepts of both resilience (the capacity of systems to buffer the shocks and stresses) and persistence (the capacity of systems to continue over long periods) and addresses many wider economic, social and environmental outcomes (Pretty, 2008). The Intergovernmental Panel on Climate Change (IPCC) defines resilience as, "the ability of a system and its component parts to anticipate, absorb, accommodate or recover from the effects of a hazardous event in a timely and efficient manner, through ensuring the preservation, restoration or improvement of its essential basic structures and functions" (IPCC, 2012).

The water sector, including irrigated agriculture is by nature prone to risks and uncertainties of various aspects such as biophysical, abiotic, climatic, environmental, biotic (pests, diseases), economic and price-related risks, and political instability. Many of these risks have a climatic component and most of them will be affected by climate change (CC), either in intensity, scope or frequency. Depending on household or system vulnerability, the system will be more or less affected by the same shock. Recovery from shocks and stresses of a system depend on its level of resilience (Gitz and Meybeck, 2012).

A resilient agriculture is one that meets both food and development needs over both short and long-terms, from local to global scales, without destabilizing the earth system. The goal of the resilient agriculture is to enable a system to respond to changing conditions, so that, there are minimal losses to the system and maintain socio-ecological system stability. A more resilient agriculture will need to be persistent, adaptive, and transformative at the shocks and stresses in time with a broader set of mechanisms, such as the social networks, governance, and leaderships to meet the immediate needs of people (Vallée, 2008).

\section{Problem identification and justification}

Increasing water scarcity is one of the major global challenges today (Jacobson et al., 2013). It is estimated that by 2025 , most of the districts in the Dry and Intermediate zones of Sri Lanka will face severe seasonal or year-round absolute water scarcity at the current level of irrigation efficiency (Amarasinghe et al., 1999). In Yala or minor season, 60\% of lands under MIS are not cultivated due to water scarcity or shortage. It is known that rain fed agriculture followed by minor irrigation would likely be the most vulnerable and first casualty of impacts of CC in the agriculture sector (Aheeyar, 2015). With the changes in the eco-system and socio-economic conditions, farmers in MIS experience many difficulties that affect their livelihood. In order to address this problem in Sri Lanka, it is recommended to concentrate on smart investments and adaptation interventions (Bronzoni, 2015), to create "resilience" to water scarcity as well as CC among vulnerable groups while addressing "current development goals". However, the limitation is that there is no proper and well- established performance evaluation method for assessing the resilience of irrigated agricultural systems.

Therefore, this study was conducted to provide a framework and prospective methodology for assessing resilience and determine the outcomes of institutions aimed at enhancing resilience to shocks and stresses of MIS. In an effort to ground the conceptual and technical discussions of resilience, the study has also aimed to identify key challenges to achieve resilience and describes necessary steps for moving the resilience agenda forward in the MIS. 


\section{MATERIALS AND METHODS}

\section{Study area}

This study was conducted in three ASDs, namely Kumbukgate, Kobeigane and Rasnayakapura in $\mathrm{IL}_{3}$ agro-ecological region in Kurunegala district $\left(7^{\circ} 45^{\prime} \mathrm{N} 80^{\circ} 15^{\prime} \mathrm{E}\right)$ in North Western Province of Sri Lanka (Figure 1). This agro-ecological region lies in the western half of the island and has mild drought conditions during Maha season due to the relatively low contribution of rains from the northeast monsoon. When rainfall during March is ineffective, it falls under the category of an area prone to severe drought conditions during Yala season (Chithranayana and Punyawardena, 2008).

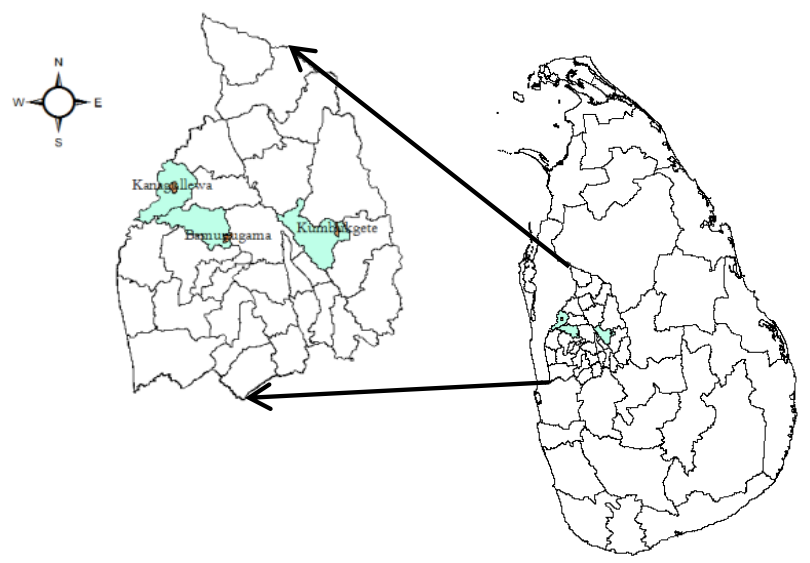

Figure 1. Study areas

\section{Framework to assess resilience to farming in MIS}

The resilience of a system to shocks and stresses depends on the exposure, sensitivity and adaptive capacity of the system (Frankenberger et al., 2012). In that, exposure and sensitivity depend on the frequency of disasters and environmental conditions. Adaptive capacity can be managed by implementing different risk management strategies within the system. Therefore, the resilience of farming is measured using adaptive capacity or the risk management strategies used in their households related to farming practices. Previous studies conducted to assess the vulnerability and resilience to $\mathrm{CC}$ induced shocks includes socioeconomic and political status of individuals or social groups (Tesso et al., 2012). Resilience is delineated into three major categories such as farming assets (including labor, land, water and accessibility of inputs and services related to farming), farming strategies (including different farming techniques) and governance or institutional support as shown in Figure 2 . 


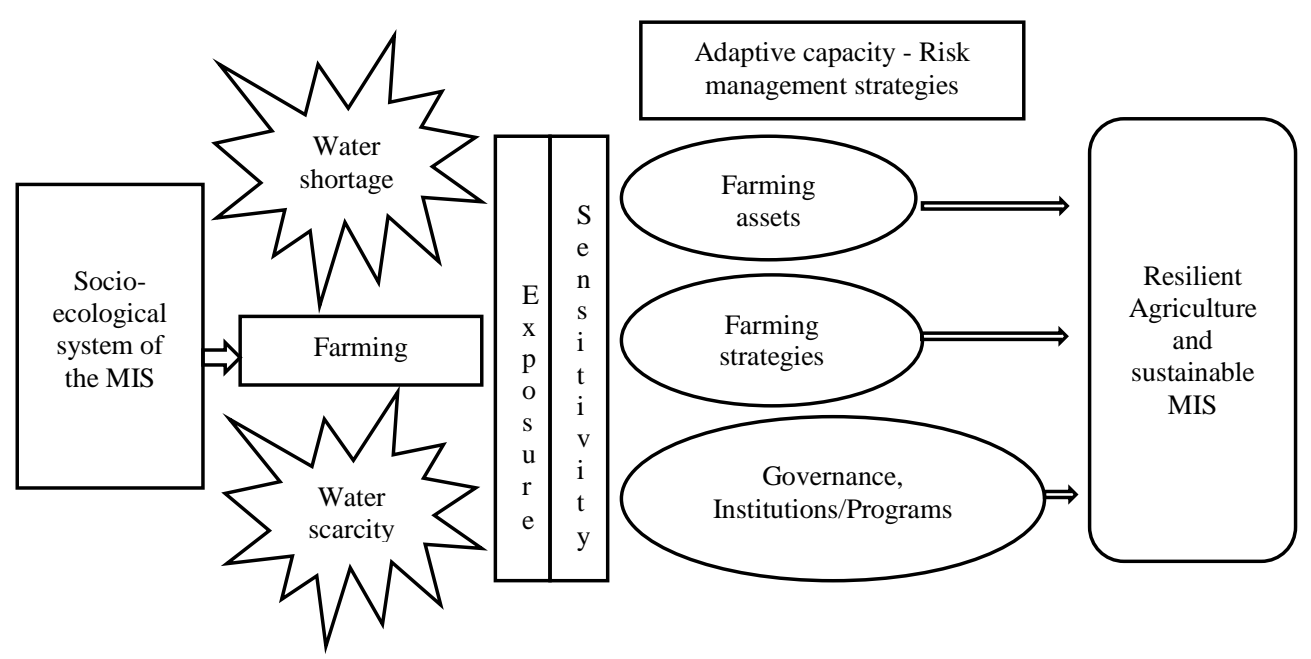

Figure 2. Framework to assess the resilience to farming in MIS

Among those identified possible risks management strategies, 20 strategies were filtered as most relevant aspects to be used as indicators to predict farmers' resilience in different irrigation systems in the study area (Table 1).

Table 1. Variables used to measure resilience

\begin{tabular}{|c|c|}
\hline Criteria & Variables \\
\hline Farming assets & $\begin{array}{l}\text { 1. Educational status of the farmers } \\
\text { 2. Participation in agricultural training programmes } \\
\text { 3. Paddy land productivity } \\
\text { 4. Adequacy of irrigation water } \\
\text { 5. Fair distribution of irrigation water } \\
\text { 6. Flexibility within the field canal to change irrigation rotation } \\
\text { 7. } \\
\end{array}$ \\
\hline $\begin{array}{l}\text { Farming } \\
\text { strategies }\end{array}$ & $\begin{array}{l}\text { 8. Practice water conservation cultivation measures } \\
\text { 9. Organic fertilizer usage } \\
\text { 10. Accessibility of agricultural input market } \\
\text { 11. Number of information sources } \\
\text { 12. Enrolled in livestock farming }\end{array}$ \\
\hline $\begin{array}{l}\text { Governance, } \\
\text { Institutions/ } \\
\text { Programmes }\end{array}$ & $\begin{array}{l}\text { 13. Farmers perception on the status of their FO } \\
\text { 14. Effectiveness of the Kanna (seasonal) meeting } \\
\text { 15. Support services provided by Department of Agrarian } \\
\text { Development (DAD) } \\
\text { 16. Coordination between farmers and DAD } \\
\text { 17. Farmers' perception on the role of the president of FO } \\
\text { 18. Farmers' perception on the role of the Jalapalaka } \\
\text { 19. Farmers' perception on the role of the Agricultural Research } \\
\text { and Production Assistant (KUPANISA) } \\
\text { 20. Farmers' perception on the role of the Divisional Officer } \\
\text { (DO) of DAD }\end{array}$ \\
\hline
\end{tabular}




\section{Data collection}

Primary information was collected through structured questionnaire survey, which was carried out at 188 households belonging to eight FOs under the 16 MIS in Kumbukgate, Bamunugama and Kanagullawa Grama Niladari (GN) divisions in Kumbukgate, Kobeigane and Rasnayakapura ASDs, respectively. Stratified random sampling was applied based on FO level. Sample was calculated as 30 percent propotion to the number of members in each FO. But, altogether 188 households were surveyed (Table 2).

Basic information regarding tank condition on the selected village tanks (Table 3) was collected from DAD and observations were made during field visits with regard to the present situation of the selected tanks.

\section{Data analyses}

After obtaining individual information, collected information was clustered into each tank using frequency of farmer responses within each variable. Weightages were given allowing the positive side of the variable representing the highest resilience of maximum 100, and a minimum of 0 to represent the lowest resilience situation within the variable. Therefore, entire data set was converted into the percentage (0\% to 100\%) scale for the analysis. Table 4 represents the predicted values of variables for each tank. Statistical analyses were performed using Statistical Package for the Social Sciences (SPSS). Clustered information or the processed values of variables were used to analyze the resilience component. For that factor analysis was performed with the principle component method and rotated (from Varimax with Kaiser Normalization technique) factor loadings were extracted to compute resilience index. 
Table 2. Distribution of sample size of each FOs and tanks

\begin{tabular}{|c|c|c|c|c|c|c|c|}
\hline FO name & $\begin{array}{c}\text { FO } \\
\text { name } \\
\text { code } \\
\end{array}$ & $\begin{array}{c}\text { Number of } \\
\text { member } \\
\text { farmers }\end{array}$ & $\begin{array}{c}\text { Number of } \\
\text { surveyed } \\
\text { farmers } \\
\end{array}$ & Tank name & $\begin{array}{c}\text { Tank } \\
\text { name } \\
\text { code }\end{array}$ & $\begin{array}{c}\text { Number of } \\
\text { member } \\
\text { farmers }\end{array}$ & $\begin{array}{c}\text { Number of } \\
\text { surveyed } \\
\text { farmers } \\
\end{array}$ \\
\hline \multirow{2}{*}{$\begin{array}{l}\text { Disanaggama } \\
\text { Kumbukgate }\end{array}$} & \multirow{2}{*}{ DK } & \multirow{2}{*}{33} & \multirow{2}{*}{11} & Ddisanakgama wewa & DW & 18 & 6 \\
\hline & & & & Kubukgate wewa & KUW & 13 & 5 \\
\hline Pothana & $\mathrm{PO}$ & 33 & 19 & Pothana wewa & POW & 33 & 19 \\
\hline \multirow{3}{*}{ Kombuwa } & \multirow{3}{*}{$\mathrm{KO}$} & \multirow{3}{*}{57} & \multirow{3}{*}{35} & Kombuwamaha wewa & KKW & & 19 \\
\hline & & & & Kombuwakuda wewa & KMW & 57 & 7 \\
\hline & & & & Kombuwapansal wewa & PAW & & 9 \\
\hline \multirow{2}{*}{ Shakthi } & \multirow{2}{*}{ SHA } & \multirow{2}{*}{41} & \multirow{2}{*}{12} & Bogaha wewa & BOW & 14 & 4 \\
\hline & & & & Rathmalagas wewa & RW & 27 & 8 \\
\hline \multirow{2}{*}{ Sriparakrama } & \multirow{2}{*}{$\mathrm{SP}$} & \multirow{2}{*}{104} & \multirow{2}{*}{35} & Kirimatiya wewa & KIW & 87 & 32 \\
\hline & & & & Wadu wewa & WW & 3 & 3 \\
\hline Isuru & ISU & 27 & 11 & Mellagandas wewa & MW & 27 & 11 \\
\hline \multirow{4}{*}{ Samagi } & \multirow{4}{*}{$\mathrm{SA}$} & \multirow{4}{*}{97} & \multirow{4}{*}{48} & Gala wewa & GW & 31 & 15 \\
\hline & & & & Kanagullewa wewa & KAW & 15 & 14 \\
\hline & & & & Manaweriya wewa & MAW & 6 & 4 \\
\hline & & & & Pin wewa & PIW & 16 & 15 \\
\hline Vijayaba & VI & $\begin{array}{c}23 \\
415\end{array}$ & $\begin{array}{c}17 \\
188\end{array}$ & Haba wewa & HW & 17 & 16 \\
\hline
\end{tabular}


Table 3. Basic information of the selected tanks (Source: Dept. of Agrarian Development Database, 2016)

\begin{tabular}{|c|c|c|c|c|c|c|c|c|c|c|c|c|c|c|}
\hline \multirow{2}{*}{ Tank no } & \multirow{2}{*}{$\begin{array}{l}\text { Name of } \\
\text { scheme }\end{array}$} & \multirow{2}{*}{ 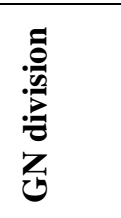 } & \multirow{2}{*}{ 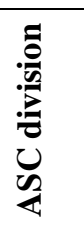 } & \multirow{2}{*}{ 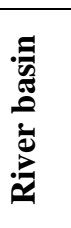 } & \multicolumn{3}{|c|}{ Tank condition } & \multirow{2}{*}{ 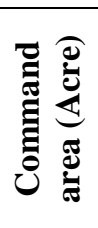 } & \multirow{2}{*}{ 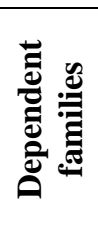 } & \multirow{2}{*}{$\frac{n}{0}$} & \multirow{2}{*}{ 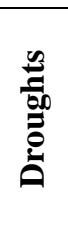 } & \multirow{2}{*}{ 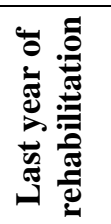 } & \multirow{2}{*}{ 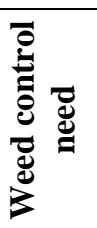 } & \multirow{2}{*}{ 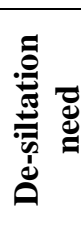 } \\
\hline & & & & & 兰 & $\stackrel{\stackrel{\Xi}{\Xi}}{\mathscr{E}}$ & 言常 & & & & & & & \\
\hline 994 & DW & 429 & 18 & 99 & 3 & 3 & & 8 & 23 & 1 & & 2013 & 1 & 1 \\
\hline 993 & KUW & 429 & 18 & 99 & 2 & 4 & 2 & 10 & 23 & 1 & & & 1 & 1 \\
\hline 991 & POW & 429 & 18 & 99 & 3 & 1 & 1 & 29 & 33 & 1 & & 2013 & 1 & 1 \\
\hline 995 & KKW & 429 & 18 & 99 & 3 & 3 & 1 & 33 & 54 & 1 & & 2013 & 1 & 1 \\
\hline 997 & KMW & 429 & 18 & 99 & 2 & 3 & 4 & 24 & 54 & 1 & & & 1 & 1 \\
\hline 996 & PAW & 429 & 18 & 99 & 2 & 2 & 3 & 12 & 20 & 1 & & & 1 & 1 \\
\hline 4970 & BOW & 1294 & 5 & 99 & 1 & 2 & 2 & 11 & 13 & & & 2014 & 1 & 1 \\
\hline 4969 & RW & 1294 & 5 & 99 & 2 & 1 & 1 & 16 & 34 & & & 2014 & 1 & 1 \\
\hline 4971 & KIW & 1294 & 5 & 99 & 2 & 2 & 2 & 63 & 80 & & & 2014 & 1 & 1 \\
\hline 4972 & WW & 1294 & 5 & 99 & 2 & 2 & 2 & 3 & 3 & & & & 1 & 1 \\
\hline 4965 & MW & 1294 & 5 & 99 & 2 & 1 & 1 & 12 & 22 & & & & 1 & 1 \\
\hline 4763 & GW & 277 & 3 & 98 & 3 & 3 & 2 & 55 & 45 & & 1 & 2002 & 2 & 1 \\
\hline 4764 & KAW & 277 & 3 & 98 & 3 & 1 & 1 & 42 & 26 & & 1 & 2014 & 2 & 2 \\
\hline 4773 & MAW & 277 & 3 & 98 & 2 & 2 & 2 & 9 & 7 & & 1 & & 1 & 1 \\
\hline 4766 & PIW & 277 & 3 & 98 & 2 & 3 & 3 & 24 & 15 & & 1 & 2010 & 2 & 2 \\
\hline 4950 & HW & 277 & 3 & 98 & 2 & 2 & 2 & 33 & 20 & & 1 & 2016 & 2 & 2 \\
\hline
\end{tabular}

GN division 1429 - Kumbukgate, 1294 - Bamunugama, 277 - Kanagullawa

River basin 199 - Daduru oya, 98 - Rathambala oya

ASC division 118 - Kumbukgate, 5 - Kobeigane, 3 - Rasnayakapura

Tank condition /1-Very good, 2- Normal, 3 Week, 4-Abandoned, 5 - Flood affected

Floods/Droughts/1 - Yes, 2 - No

Weed control/Desolation /1 - Need, 2 - Not need 
Table 4. Distribution of predicted values of variables within tank level

\begin{tabular}{|c|c|c|c|c|c|c|c|c|c|c|c|c|c|c|c|c|}
\hline Variables & DW & KUW & POW & $\begin{array}{c}\mathbf{K K} \\
\mathbf{W}\end{array}$ & $\begin{array}{c}\mathbf{K M} \\
\mathbf{W}\end{array}$ & $\begin{array}{c}\text { PA } \\
\mathbf{W}\end{array}$ & $\begin{array}{c}\text { BO } \\
\text { W }\end{array}$ & $\mathbf{R W}$ & $\begin{array}{l}\mathbf{K I} \\
\mathbf{W}\end{array}$ & $\mathbf{W W}$ & $\begin{array}{l}\mathbf{M} \\
\mathbf{W}\end{array}$ & GW & $\begin{array}{c}\mathbf{K A} \\
\mathbf{W}\end{array}$ & $\begin{array}{c}\text { MA } \\
\text { W }\end{array}$ & PIW & HW \\
\hline 1 & 50.0 & 45.0 & 44.7 & 42.9 & 47.4 & 52.8 & 50.0 & 59.4 & 57.0 & 50.0 & 40.9 & 40.0 & 44.6 & 25.0 & 50.0 & 39.7 \\
\hline 2 & 16.7 & 0.0 & 0.0 & 14.3 & 15.8 & 11.1 & 0.0 & 0.0 & 21.9 & 0.0 & 18.2 & 6.7 & 6.7 & 66.7 & 20.0 & 5.9 \\
\hline 3 & 27.0 & 14.1 & 56.7 & 100 & 65.2 & 57.2 & 37.8 & 47.1 & 55.6 & 0.0 & 59.7 & 47.4 & 54.0 & 45.7 & 40.6 & 76.8 \\
\hline 4 & 66.7 & 50.0 & 50.0 & 50.0 & 52.6 & 55.6 & 0.0 & 25.0 & 78.1 & 16.7 & 40.9 & 83.3 & 86.7 & 50.0 & 73.3 & 64.7 \\
\hline 5 & 100 & 100 & 100 & 100 & 89.5 & 55.6 & 50.0 & 87.5 & 50.0 & 0.0 & 81.8 & 66.7 & 66.7 & 66.7 & 66.7 & 94.1 \\
\hline 6 & 100 & 100 & 94.7 & 85.7 & 100 & 88.9 & 100 & 100 & 93.8 & 100 & 45.5 & 100 & 100 & 33.3 & 100 & 52.9 \\
\hline 7 & 100 & 100 & 94.7 & 71.4 & 86.8 & 77.8 & 100 & 87.5 & 73.4 & 66.7 & 81.8 & 80.0 & 83.3 & 100 & 80.0 & 70.6 \\
\hline 8 & 0.0 & 20.0 & 42.1 & 0.0 & 5.3 & 0.0 & 0.0 & 11.1 & 21.9 & 66.7 & 27.3 & 46.7 & 28.6 & 0.0 & 56.3 & 50.0 \\
\hline 9 & 100 & 100 & 68.4 & 85.7 & 100 & 100.0 & 0.0 & 100 & 40.6 & 66.7 & 63.6 & 66.7 & 73.3 & 0.0 & 53.3 & 82.4 \\
\hline 10 & 100 & 35.0 & 73.7 & 50.0 & 47.4 & 52.8 & 50.0 & 50.0 & 48.4 & 33.3 & 40.9 & 51.7 & 41.1 & 50.0 & 33.3 & 35.3 \\
\hline 11 & 41.7 & 30.0 & 67.1 & 46.4 & 31.6 & 58.3 & 50.0 & 59.4 & 56.3 & 75.0 & 34.1 & 55.0 & 55.4 & 62.5 & 63.3 & 48.5 \\
\hline 12 & 16.7 & 0.0 & 15.8 & 10.5 & 0.0 & 22.2 & 0.0 & 25.0 & 25.0 & 0.0 & 18.2 & 13.3 & 7.1 & 50.0 & 26.7 & 5.9 \\
\hline 13 & 70.8 & 55.0 & 82.9 & 71.4 & 75.0 & 69.4 & 87.5 & 65.6 & 64.8 & 33.3 & 68.2 & 73.3 & 63.3 & 66.7 & 75.0 & 85.3 \\
\hline 14 & 100 & 100 & 100 & 100 & 100 & 100.0 & 100 & 87.5 & 56.3 & 33.3 & 81.8 & 100 & 100 & 66.7 & 100 & 100 \\
\hline 15 & 91.7 & 10.0 & 52.6 & 50.0 & 50.0 & 50.0 & 75.0 & 56.3 & 46.9 & 33.3 & 50.0 & 50.0 & 50.0 & 16.7 & 56.7 & 50.0 \\
\hline 16 & 50.0 & 40.0 & 47.4 & 42.9 & 50.0 & 50.0 & 50.0 & 43.8 & 40.6 & 33.3 & 50.0 & 40.0 & 39.3 & 25.0 & 46.7 & 76.5 \\
\hline 17 & 50.0 & 50.0 & 86.8 & 64.3 & 89.5 & 66.7 & 75.0 & 65.6 & 46.9 & 50.0 & 75.0 & 55.0 & 51.8 & 62.5 & 60.0 & 79.4 \\
\hline 18 & 50.0 & 50.0 & 84.2 & 57.9 & 50.0 & 50.0 & 75.0 & 62.5 & 64.8 & 66.7 & 79.5 & 58.3 & 55.4 & 75.0 & 63.3 & 82.4 \\
\hline 19 & 50.0 & 50.0 & 84.2 & 78.9 & 57.1 & 61.1 & 50.0 & 62.5 & 53.9 & 50.0 & 65.9 & 65.0 & 48.2 & 37.5 & 70.0 & 79.4 \\
\hline 20 & 50.0 & 50.0 & 55.3 & 47.4 & 53.6 & 50.0 & 50.0 & 62.5 & 56.3 & 66.7 & 29.5 & 45.0 & 48.2 & 31.3 & 53.3 & 55.9 \\
\hline
\end{tabular}




\section{RESULTS AND DISCUSSION}

\section{Socio economic background of the study area}

According to survey data, 72 percent of households are engaged in irrigated agriculture or paddy farming as their major occupation. All the sampled households, who cultivate paddy, are abstracting water from village tanks. About 68 percent of surveyed farmers had cultivated both seasons, whilst 32 percent cultivated only during Maha season. This information suggests that many farming communities of MIS across the region are at significant risk, if agriculture systems are stressed by events such as droughts due to water scarcity.

Among the responded farmers, the majority of them (about 93 percent) are above 49 years of age, indicating the less involvement of youth in farming activities. Only 6 percent of the total farmers represents the youths under 35 years of age. These findings reveal that a segment of the young population is either in employment seeking category or employed in outside of the agriculture sector. The statistics of the education of the respondent farmers show that the majority of them (67 percent) have received formal education from grade six to G.C.E (O/L) and 19 percent have received only primary education. Educational background of the farmers implied that the irrigated farming community in the study area has sufficient educational background to capture the irrigation system management programmes, new technological innovations and new knowledge from climate awareness programmes. Therefore, empowerment of farmers could be handled conveniently to implement necessary adaptation measures.

Paddy land distribution in the study areas showed that average lowland extent of 0.47 ha per household. The majority of farmers (71 percent) are having low land extent below 0.405 ha $(1 \mathrm{ac})$. The maximum and minimum extent of low land recorded was $2.03 \mathrm{ha}(5 \mathrm{ac})$ and 0.10 ha $(0.25 \mathrm{ac})$, respectively.

\section{Farmer's resilience to farming in MIS}

The estimates obtained from the resilience analysis are reported in the flowing sections. The high correlation among variables can produce latent variables or factors considered to measure resilience. Extracted factor loadings (value $>0.5$ ( + or -$)$ ) to measure different factors are shown in Table 5. 
Table 5. Extracted factor loadings for the observed variables used to estimate the factors related to resilience

\begin{tabular}{|c|c|c|c|c|c|c|}
\hline \multicolumn{7}{|c|}{ Rotated Component Matrix ${ }^{a}$} \\
\hline & \multicolumn{6}{|c|}{ Component } \\
\hline & F1 & F2 & F3 & F4 & F5 & F6 \\
\hline Education status of farmers & .842 & & & & & \\
\hline Participation in Agric. training & -.852 & & & & & \\
\hline Flexibility within field canal & .840 & & & & & \\
\hline Organic fertilizer usage & .559 & & & & & \\
\hline Livestock farming & -.659 & & & & & \\
\hline Perception regarding DO & .831 & & & & & \\
\hline Land productivity & & .765 & & & & \\
\hline Strength of FO & & .741 & & .513 & & \\
\hline Coordination with DAD & & .790 & & & & \\
\hline $\begin{array}{l}\text { Perception regarding FO } \\
\text { president }\end{array}$ & & .741 & & & & \\
\hline Perception regarding KUPANISA & & .847 & & & & \\
\hline Fair distribution of water & & & .658 & & & \\
\hline Number of information source & & & -.885 & & & \\
\hline Productivity of Kanna meeting & & & .621 & & & \\
\hline $\begin{array}{l}\text { Minimum wastage within field } \\
\text { canal }\end{array}$ & & & & .681 & & \\
\hline Agric. Input market & & & & .838 & & \\
\hline Support services from DAD & & & & .666 & & \\
\hline Adequacy of water to farming & & & & & .918 & \\
\hline Water conservation farming & & & & & & .733 \\
\hline Perception regarding Jalapalaka & & & & & & \\
\hline
\end{tabular}

Factor representing the contribution from the total is calculated as a fraction for resilience index as shown in Table 6.

The value of the selected factor loadings was multiplied by predicted values of variables from different tanks and summation of relevant variables were taken as the values of extracted factors (Table 7). 
Table 6. Fraction of the factors in resilience index

\begin{tabular}{ccc}
\hline Factor & \% Variance & Fraction \\
\hline F1 & 21.470 & 0.254765 \\
F2 & 20.255 & 0.240343 \\
F3 & 14.034 & 0.166522 \\
F4 & 12.593 & 0.149428 \\
F5 & 9.392 & 0.111449 \\
F6 & 6.531 & 0.077499 \\
Total & 84.275 & 1 \\
\hline
\end{tabular}

Accordingly, the empirical equation to calculate resilience index was given as;

$$
\mathrm{R}=0.25 * \mathrm{~F} 1+0.24 * \mathrm{~F} 2+0.17 \mathrm{~F} 3+0.15 \mathrm{~F} 4+0.11 \mathrm{~F} 5+0.08 \mathrm{~F} 6
$$

Resilience index is divided into three categories as high $(>0.75)$, moderate $(0.50-0.75)$ and low $(<0.50)$. The total resilience index value of 0.555 represents moderate resilience situations within the MIS in $\mathrm{IL}_{3}$ agro-ecological region in the Kurunegala district. This shows that there is adequate space to enhance the resilience of farming by introducing and adapting various risk management strategies in this region. According to the results, Pothana wewa (0.637) was found to be the most resilient among the tested tanks, followed by Dissanaggama wewa (0.614) and Haba wewa (0.600). Whilst most of the tanks showed a resilience index around 0.5 , only two tanks, namely, Waduwage wewa (0.432) and Manaweriaya wewa (0.466) scored a resilience index of less than 0.5 .

Although there is no significant relationship between the capacity of the tank and the resilience situation, tanks with lower capacity and command area tends to be less resilient than larger tanks. The smallest tanks among the sample such as Wadu wewa, Manaweriya wewa and Kumbukgate wewa are the least resilient tanks, which feed below 10 ac of command area. However, Dissanaggama wewa, which provides water to 8 ac command area showed comparatively high resilience. The reasons for such high resilience were due to the accessibility of services and the trust of the farmers both on their FO and the agency officials. 
Table 7. Extracted factors related to resilience and computed resilience index

\begin{tabular}{|c|c|c|c|c|c|c|c|c|c|c|c|}
\hline FO Names & $\begin{array}{c}\text { Tanks } \\
\text { Names }\end{array}$ & F1 & F2 & F3 & F4 & F5 & F6 & $\begin{array}{l}\text { Resilience } \\
\text { (R) }\end{array}$ & $\begin{array}{c}\text { Resilience } \\
\text { index } \\
\text { (tanks) }\end{array}$ & $\begin{array}{c}\text { Resilience } \\
\text { index } \\
\text { (FOs) }\end{array}$ & $\begin{array}{l}\text { Resilience } \\
\text { index } \\
\text { (ASD) }\end{array}$ \\
\hline \multirow{2}{*}{ DK } & DW & 248.733 & 215.911 & 164.775 & 239.876 & 61.200 & 0.000 & 184.727 & 0.614 & \multirow{2}{*}{0.559} & \multirow{6}{*}{0.587} \\
\hline & KUW & 219.340 & 190.005 & 154.450 & 124.997 & 45.900 & 14.660 & 151.664 & 0.504 & & \\
\hline \multirow[t]{2}{*}{$\mathrm{PO}$} & POW & 211.824 & 293.427 & 187.288 & 192.827 & 45.900 & 30.863 & 191.660 & 0.637 & \multirow[t]{2}{*}{0.637} & \\
\hline & KKW & 214.471 & 281.156 & 168.989 & 150.995 & 45.900 & 0.000 & 177.522 & 0.590 & & \\
\hline \multirow[t]{2}{*}{$\mathrm{KO}$} & KMW & 237.755 & 272.811 & 148.921 & 160.644 & 48.316 & 3.858 & 179.950 & 0.598 & \multirow[t]{2}{*}{0.590} & \\
\hline & PAW & 240.667 & 251.254 & 150.281 & 156.893 & 51.000 & 0.000 & 175.159 & 0.582 & & \\
\hline \multirow{2}{*}{ SHA } & BOW & 167.650 & 251.988 & 139.250 & 193.212 & 0.000 & 0.000 & 155.044 & 0.515 & \multirow{2}{*}{0.553} & \multirow{5}{*}{0.517} \\
\hline & RW & 258.306 & 238.995 & 164.459 & 163.896 & 22.950 & 8.144 & 177.654 & 0.590 & & \\
\hline \multirow{2}{*}{ SP } & KIW & 231.336 & 218.905 & 117.613 & 146.470 & 71.719 & 16.034 & 161.508 & 0.537 & \multirow{2}{*}{0.484} & \\
\hline & WW & 218.767 & 161.875 & 87.075 & 108.204 & 15.300 & 48.867 & 130.167 & 0.432 & & \\
\hline \multirow[t]{2}{*}{ ISU } & MW & 160.225 & 261.781 & 134.816 & 149.218 & 37.555 & 19.991 & 153.915 & 0.511 & \multirow[t]{2}{*}{0.511} & \\
\hline & GW & 206.808 & 236.142 & 154.642 & 158.953 & 76.500 & 34.207 & 169.660 & 0.564 & & \\
\hline \multirow{3}{*}{ SA } & KAW & 213.036 & 214.781 & 154.958 & 148.543 & 79.560 & 20.943 & 163.858 & 0.544 & \multirow{3}{*}{0.542} & \\
\hline & MAW & 164.769 & 200.775 & 140.579 & 146.442 & 45.900 & 0.000 & 140.292 & 0.466 & & 0.553 \\
\hline & PIW & 234.847 & 247.294 & 162.017 & 148.663 & 67.320 & 41.231 & 178.608 & 0.593 & & \\
\hline \multirow[t]{3}{*}{ VI } & HW & 179.265 & 318.341 & 166.978 & 143.370 & 59.400 & 36.650 & 180.576 & 0.600 & 0.600 & \\
\hline & $\begin{array}{c}\text { Total } \\
\text { sample }\end{array}$ & 212.987 & 240.965 & 149.818 & 158.325 & 48.401 & 17.216 & 166.998 & 0.555 & 0.555 & 0.555 \\
\hline & $\begin{array}{c}\text { Ideal } \\
\text { situation }\end{array}$ & 458.300 & 388.400 & 216.400 & 269.800 & 91.800 & 73.300 & 301.011 & 1.000 & 1.000 & 1.000 \\
\hline
\end{tabular}




\section{Resilience index by minor tanks level}

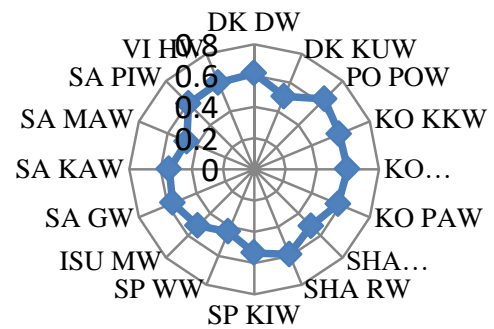

\section{Resilience index by FO level}

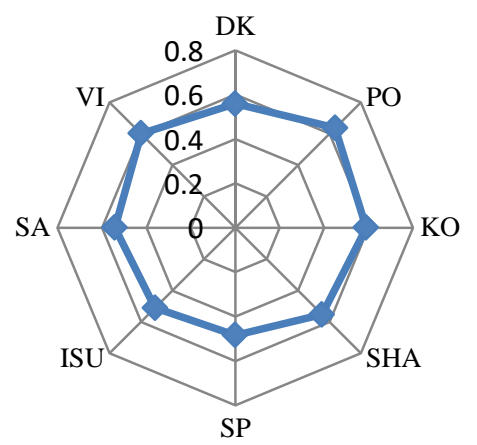

Figure 3. Resilience index by minor tanks and FOs level

It was also found that least resilient tanks have not been rehabilitated recently, though the sluice, spillway and tank bund appear to be in working condition. Aquatic plants control such as Salvinia, Water Hyacinth and de-siltation are the critical problems, which need to be addressed without further delay.

There is strong relationship between the land productivity and the resilience index. The tanks with low resilient index, such as Wadu wewa and Kumbukgate wewa has a land productivity of $2.1 \mathrm{t} / \mathrm{ha}$ and $2.6 \mathrm{t} / \mathrm{ha}$ respectively. The maximum productivity of $5.4 \mathrm{t} / \mathrm{ha}$ was recorded in Kombuwa kuda wewa with a resilience index of 0.59 . The land productivity of most resilient tank within the sample, namely, Pothana wewa with $4 \mathrm{t} / \mathrm{ha}$ was found to be above the average value of $3.7 \mathrm{t} / \mathrm{ha}$. It was observed that less resilient tanks did not have adequate water to cultivate both seasons. In contrast, comparatively high resilient tanks like Pothana wewa, Haba wewa etc. have adequate water to cultivate both seasons. Therefore, it is necessary to introduce water saving measures/technologies to enhance the resilience of such farmers in MIS.

Governance and institutional arrangements also have a major role in implementation of works related to farming to enhance the resilience of farmers. Personal relations of the officials and farmers and the trust on FOs have made a considerable difference in the resilience situation of tanks. The result shows that, comparatively high resilient tanks represent the higher value of trust (eg: Pothana wewa, Haba wewa etc.) of their FOs activities. Farmers trust on Pothana wewa FO activities and the services provided by the officials is characterized by higher values, while Sri Parakrama FO represents the least resilience. The farmers of Sri Parakrama FO made negative comments on their FO activities and the supports provided by the officials during the field visits. 


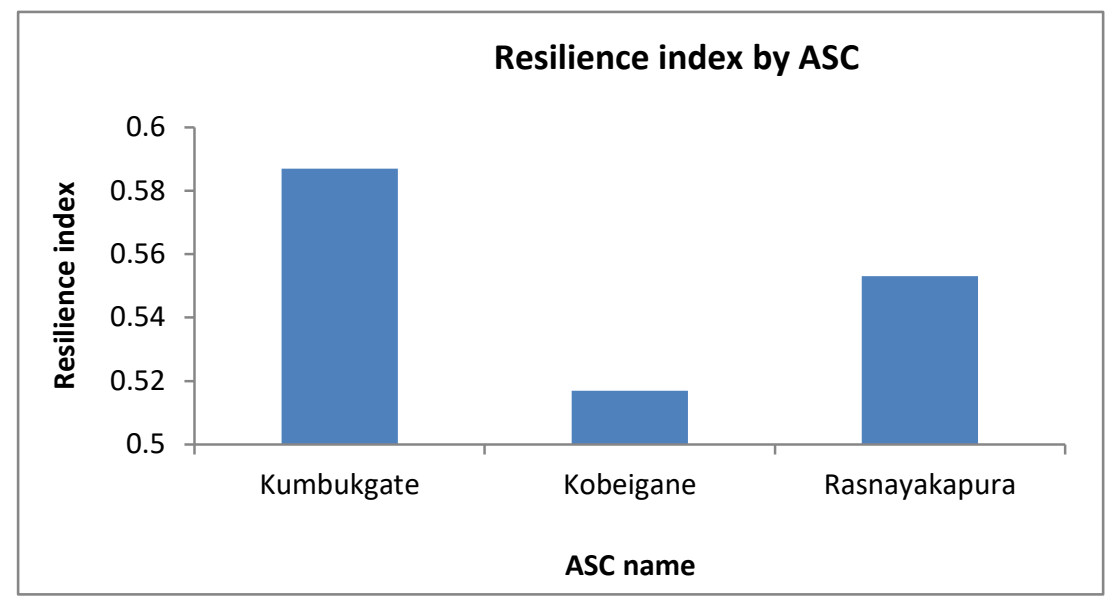

Figure 4. Resilience component by ASDs level

Figure 4 shows the average resilience index of tanks belongs to three ASDs. The differences of resilience index are mainly due to the accessibility to market facilities. It is high in Kumbukgate ASD followed by Rasnayakapura and Kobeigane.

\section{CONCLUSIONS}

Using the empirical equation derived from the study, the resilience of MIS was quantitatively determined. The results showed that resilient component of each MIS as well as FO is fluctuating around the mid value (0.5), implying that there is adequate space to enhance the resilience of farming in MIS by introducing and adapting various risk management strategies. It appears that farming assets, farming strategies and institutional interventions are important to enhance resilience. In addition, capacity of the tank, accessibility of support services and the trust of farmers on FOs and the agency officials are some of the key factors, which determine the resilience of farming in MIS. Therefore, to enhance the resilience, it is recommended to augment tank storage by removing aquatic weeds and de-silting, introduce water saving measures/technologies, strengthen the FOs, improve governance of MIS and develop access to market facilities.

\section{ACKNOWLEDGEMENT}

This study was carried out with the aid of a grant from the International Development Research Centre (IDRC), Ottawa, Canada. Their financial support is greatly acknowledged.

\section{REFERENCES}

Aheeyar, M.M.M. (2015). Resilience of irrigated farmers to climate change effects. Survey report submitted to the Sri Lanka Water Partnership Colombo. Lanka Jalani Global Water Partnership South Asia, Colombo, Sri Lanka. 
Amarasinghe, U.A., Mutuwatta, L., Sakthivadivel, R. (1999). Water scarcity variations within a country: a case study of Sri Lanka. Colombo, Sri Lanka: International Water Management Institute (IWMI). vi, p.28. (IWMI Research Report 032) doi: http://dx.doi.org/10.3910/2009.038.

Bronzoni, G. (2015). Operation and maintenance of minor irrigation tanks [on line]. [Accessed on 17.05.2016]. Available at http://www.fao.org/srilanka/news/detailevents/en/c/343804/

Chithranayana, R.D. and Punyawardena, B.V.R. (2008). Identification of drought prone agro-ecological regions in Sri Lanka. Journal of National Science Foundation of Sri Lanka, $36(2), 117-123$.

Department of Agrarian Development (2016). Updated Database, Water Management Division, Department of Agrarian Development, Sri Lanka. Available at http://agrariandept.gov.lk:8008/agrarian/home.jsp\#

Frankenberger, T., Spangler, T., Nelson, S. and Langworthy, M. (2012). Enhancing Resilience to Food Security Shocks in Africa [on line]. [Accessed on 20.03.16]. Available at http://www.fsnnetwork.org/sites/default/files/discussion_paper_usaid_dfid_wb_nov._8_201 2.pdf

Gitz, V. and Meybeck, A. (2012). Risks, vulnerabilities and resilience in a context of climate change. Building resilience for adaptation to climate change in the agriculture sector $23, \mathrm{p}$. 19.

International Water Management Institute (IWMI), (2006). Development strategy for the irrigation sector of Sri Lanka 2006-2016. International Water Management Institute, Colombo, Sri Lanka.

IPCC (2012). Managing the risks of extreme events and disasters to advance climate change adaptation. A special report of working groups I and II of theIntergovernmental Panel on Climate Change [Field, C.B., V. Barros, T.F. Stocker,D. Qin, D.J. Dokken, K.L. Ebi, M.D. Mastrandrea, K.J. Mach, G.-K. Plattner, S.K. Allen,

M. Tignor, and P.M. Midgley (Eds.)]. Cambridge University Press, Cambridge, UK, and New York, NY, USA, $582 \mathrm{pp}$.

Jacobson, M., Meyer, F., Oia, I., Reddy, P. and Tropp, H. (2013). User's guide on assessing water governance. United Nations Development Program, UNDP Governance Centre, Denmark.

Kumara, G.M.P., Samarakon, S.M.L.D., Wijewardana, Y.G.D.P., Mowjood, M.I.M. and Galagedara, L.W. (2017). Evaluation of paddy fields system layout for other field crops in a minor irrigation system. Trop. Agric. Res. 28(4), 364-374.

Pretty, J. (2008). Agricultural sustainability: concepts, principles and evidence. Philosophical transactions of the royal society of London B, Biol. Sci. 363(1491), 447-465. 
Shantha, A.A. and Ali, B.A. (2014). Economic value of irrigation water: a case of major irrigation scheme in Sri Lanka. J. Agric. Sci. 9(1), 44-57.

Siriweera, W.I. (2002). History of Sri Lanka from Earliest Times up to the Sixteenth Century. Dayawansa Jayakody \& Company, Colombo, Sri Lanka.

Tesso, G., Emana, B. and Ketema, M. (2012). Analysis of vulnerability and resilience to climate change induced shocks in North Shewa, Ethiopia. Agric. Sci. 3(6), 871-888.

Thilakasiri, K.R., Kumara, G.M.P., Galagedara, L.W. and Mowjood, M.I.M. (2015). Strategies to improve water productivity in small tank system: A case study from Kurunegala District in Sri Lanka. Trop. Agric. Res. 26(4), 684-692.

Vallée, J.C.L. (2008). CIELAP's $4^{\text {th }}$ partnering for sustainability workshop achieving resilient agricultural systems: Innovation, people and partnerships. The workshop of foreshadow and feed into the United Nation's Commission for Sustainable Development (CSD), Ottawa, Canada.

WIjekoon, W.M.S.M., Gunawardena, E.R.N. and Aheeyar, M.M.M. (2016). Need for institutional reforms for governance of minor irrigation systems in Sri Lanka. In proceedings of the water professionals' day-2016, Cap-Net Lanka, Postgraduate Institute of Agriculture \& Geo-Informatics Society of Sri Lanka, pp. 35-48. 